\title{
Foundations of The Economics of Time and Ignorance
}

\author{
Mario J. Rizzo
}

M. Jourdain: What? When I say: "Nicole, bring me my slippers, and give me my night-cap," is that prose?

Philosophy Teacher: Yes, sir.

M. Jourdain: Good heavens! For more than 40 years I have been speaking prose without knowing it.

Molière, Le Bourgeois Gentilhomme, 1671

Yet the moment we have produced ... theories, they create new, unintended and unexpected problems, autonomous problems, problems to be discovered.

Karl R. Popper (1979: 161)

There are two very general ideas that underlie The Economics of Time and Ignorance. The first is the startled statement of M. Jourdain in Molière's play, The Would-Be Gentleman, when he says: "I have been speaking prose without knowing it."

The second is actually related. This is the philosopher Karl Popper's idea of "objective knowledge" or World Three. Once ideas are promulgated to the world, they have certain objective implications - independent of the subjective intentions of those who developed the ideas in the first place at a certain time in history and point in space. These implications are the results of human action but not of human design.

\section{The intellectual climate in the old days}

Before, however, proceeding with these themes the reader needs some background. In the late 1970s and early 1980s Jerry O'Driscoll and I were working quite deeply in the Austrian tradition. We had studied Austrian economics at least since our college days at Fordham University in the midlate 1960s. We were by no means new to the field. But we sensed two main and related problems.

The first problem was that there were many misconceptions about the nature and content of Austrian economics among the many in the economics 
profession we hoped to influence. Many then, as still today, did not see the difference between Austrian economics and libertarian political theory. Many thought that Austrian subjectivism meant some kind of irrefutable solipsism. Many thought that Austrians didn't "believe" in data. Many thought Austrians acted as if they could learn nothing from any other school of economics. In fact, one non-Austrian NYU faculty member said that we were a "mystery cult." We claimed, or so it seemed to him, that we had the key-mysterious to all others - to all economic knowledge. Finally (only because I find making this list depressing), many thought that all we could do was quote the classic Austrian economists - Mises, Hayek and so on. We had nothing new to say.

The second problem is that some of these things were true. Austrians were insular and very absorbed with their own tradition as well as highly critical of standard neoclassical economics, even in its Chicago variant. And yet there were good reasons for this. The Austrian school had been in decline. Very few economists really understood what it was. Its central concerns and principles had to be learned. Even some in Austrian circles of the 1970s were badly misinformed and needed to clarify for themselves and others the basic ideas. Most importantly, Austrians had to apply and, in many cases, contrast their approach to contemporary economic issues - both theoretical and policy - to that of other schools of economic thought. We had to show that we had a distinct intellectual product.

This is where the Molière-Popper principles come in. Our task seemed to be both to restate the fundamental ideas of Austrian economics and to do it in a way that opened the door to further ideas - advances in the system of thought. This was not and is not an easy task. Restatements tend to be backward-looking and stimulation of new research is forward-looking. A book about how great Menger, Böhm-Bawerk, Mises and Hayek were would not accomplish our goals. On the other hand, a book simply setting out a new agenda would not be easily understandable or appreciated if people didn't comprehend the basic principles of the research framework.

\section{Where we went}

Molière's character tells us to be aware of what we have been doing. Popper tells us to follow the objective implications of a line of thought even if the espousers of that line of thought did not, or do not, recognize these implications.

If there is a single, fundamental concept in the Austrian framework it has to be subjectivism, followed closely by the analysis of economic processes in time and the inescapability of uncertainty. If one looks at the Austrian contributions since the beginning, these three ideas continually appear in fundamental ways. It is impossible to imagine Austrian economics without them. It is not possible to find another significant approach in economics that lays so much importance on them. It seemed, and still seems, reasonable to begin 
from there both in systematizing Austrian economics and in laying out an agenda for future work.

Subjectivism in real time is importantly different from the static subjectivism of preferences that is an established part of standard economics. Ludwig Lachmann (1976) was insistent on this. He, as is well known, endorsed the Hayekian view that every important advance in the history of economics has been the extension of the idea of subjectivism. In Lachmann's view, this included extension to the subjective interpretation of "data" as well as to the formation and content of expectations.

O'Driscoll and I decided to state clearly the essential Austrian themes and to draw out from them implications that may have been missed or ignored in the years of stunted growth in the tradition. As Lachmann continually reminded us, Austrians were often inconsistent in their embrace of subjectivism and process analysis. Although all Austrians had recognized the limits of equilibrium analysis in the continual process of adaptation to exogenous shocks, many did not sufficiently appreciate the endogenous sources of disruption, that is, the disruptions that arise from processes of adjustment themselves. (This is why Lachmann felt the need to talk about equilibrating forces and disequilibrating forces.)

We soon discovered that seeking to extend the Austrian analysis by eliciting dormant or implicit implications of accepted strains of thought was by no means uncontroversial. Some of the most important elder figures of Austrian economics thought the book to be dangerous or subversive. Among these were Israel Kirzner (1994) and Murray Rothbard (2011). An important exception was Lachmann (1994).

Kirzner reacted strongly against the view that market processes could be seen as disequilibrating. To this day I believe that Kirzner sought to escape that conclusion by a non-empirical, definitional argument. The successful pursuit of arbitrage-profit opportunities closes gaps in the structure of prices and coordinates the plans of the relevant actors in, say, the two markets that exhibit price inconsistency. But even where entrepreneurs make mistakes, Kirzner has argued, their intention was to make profits and avoid losses and so their actions have a "tendency" to coordinate. The first point could be transformed into an empirical claim about the frequency of entrepreneurial error, viz, most or much profit-seeking results in coordinating effects. That would be acceptable as a theoretical statement or hypothesis. But the second a tendency argument - which was used to undergird the first point, is a retreat into a position with little empirical content. This non-empirical turn is surprising in view of F. A. Hayek's early recognition that once we go beyond the pure logic of choice we enter the world of empirical statements about knowledge and knowledge transmission.

Rothbard also had many criticisms - some of the most notable revolved around our using ideas derived from the philosopher Henri Bergson's perspective on the reality of time as the subjective perception of its passage. This is what we called real time or the dynamic conception of time. Rothbard 
thought it was merely fuzzy-headed thinking. This also is surprising in view of Ludwig von Mises' mostly favorable citations to Bergson in Human Action. The role that Bergson's ideas, in the air during the early twentieth century, played in the development of Frank Knight's concept of "true uncertainty" and Mises' related concept of "case probability" is manifest.

But probably the worst "sin" we committed was to try to draw some bridges and connections with those Keynesians who took seriously J. M. Keynes' views on subjectivism and measurability in economics. Many of these were in the group calling themselves Post Keynesians. They should have called themselves something else because they were only post in the sense of trying to throw off the Keynesian-neoclassical synthesis promoted by Paul Samuelson and others.

Although our attempt to start a conversation was rebuffed by Paul Davidson (1989) (on the Post Keynesian side) and by many Austrians, the idea of a conversation - not a synthesis or absorption - continues to make sense. I suspect many Austrians feared any contamination with the interventionist policies of anyone who would call himself "Keynesian." We were talking about the extent and limits of subjectivism and not about Keynes' peculiar view of liberalism.

\section{Did we say anything original and did we produce a classic?}

In one sense, it is difficult, at this stage in the development of economics, for anyone to say anything truly new. It is possible, of course, to say old ideas in the new language of mathematics and axiomatic forms. For some economists until an idea is stated formally, it is not a scientific idea. So, for example, Adam Smith said almost nothing until he was formalized by the ArrowDebreu construct.

Since Austrians do not accept such absurdities, the question could be posed: weren't all of the ideas in The Economics of Time and Ignorance previously developed elsewhere? Perhaps this is so if one includes the philosophical literature as well as the economic. But which Austrians were talking about them before we wrote? With the exception of Ludwig Lachmann, I suggest that the answer is none.

It is not arrogant to say that O'Driscoll and I jolted the Austrians and their students out of a slumber that prevented them from appreciating or even recognizing important ideas that were "out there" waiting, as it were, to be seized. This is history. Ask the generation of Austrians that immediately followed us if we had an impact on their thinking.

This brings us to the comments of Tony Endres who asks: Is The Economics of Time and Ignorance a classic? Is the book original?

It is to Professor Endres' credit that he is using relatively precise definitions of the terms "classic" and "original." We know what he is talking about. The standards he sets are very high indeed. A classic sets forth distinctive fundamental ideas that become embodied in a recognizable school or approach to economics often after some decades. We did not intend any such thing. We 
were not trying to establish a new school; we were simply trying to push an "old" school in some new directions that were consistent with its basic premises. We would be shocked if the book produced a new school - we might even condemn that!

"Originality" in Endres' sense is also a high bar. It involves not only temporal priority for an idea but its wide acceptance as intellectually valid. Here again we intended no such thing. The ideas were out there waiting to be elaborated, integrated and shown to be in the Austrian tradition. Some were clearly from Austrian economics while others were from philosophers or philosophical traditions consistent with Austrian economics. Some were unappreciated or underappreciated. In this sense "innovative" is closer to the right characterization of our book as Endres seems to say. We strove to produce a transition in which the innovations would be absorbed. So Endres' analysis is basically correct. This did not mean setting out a specific agenda, however. We urged people to add items to their own personal agendas.

\section{Whither the new generation?}

Solomon Stein and Virgil Storr are concerned about a different set of issues. Why hasn't The Economics of Time and Ignorance had more effect on the new ("third") generation of Austrian economists? They advance three hypotheses:

1. Younger scholars may have rejected the ideas in the book.

2. The advances in the book may have been so fully absorbed as to preclude the need for explicit citation.

3. The new generation of Austrians has moved on to other, more applied, issues for which the basic concerns are different from those raised in the book.

With respect to the first hypothesis, Stein and Storr say that the research of third generation scholars "reveals an appreciation for the consequences of real time and ignorance as well as an emphasis on entrepreneurship and institutions." So they reject this hypothesis.

The second hypothesis is rejected indirectly and by an inconsistent, or simply confusing, argument. In the first place, they argue that in fact the book is cited. But, possibly reacting to the claim that it is not cited enough if it were a truly influential work, they argue that Austrians have no reluctance to cite Menger, Böhm-Bawerk, Mises and other founders on basic points. Therefore, it must be the case that the book has not been so fully absorbed as to preclude citation. In other words, the bar for citation among Austrians is low. They cite all sorts of ideas from the founders that are fully absorbed!

The obvious reaction to all of this is that O'Driscoll and I are not founders of Austrian economics. So the security that perhaps over-citation of the founders gives some writers is not gained by citing us. 
What are we to conclude, however, from the discussion of the first two hypotheses? It seems that the fundamental ideas of the book have been absorbed but that Austrians do not cite the book quite as much as one might expect. We agree.

The third hypothesis is Stein and Storr's favored one. The third generation has gone on to all manner of applied issues. With regard to these issues there are many more relevant methodological and theoretical matters to discuss than those which appeared in our book. Stein and Storr mention such things as the "literary analysis of a culture's folklore and literature, ethnographic approaches and archival social history" and "experimental economic methods." They also appreciate the insufficiency of a concept of entrepreneurship that is not embedded within culture. We would have said "not embedded in real time." In fact, all of these methods and approaches amount to a recognition that economic analysis should be undertaken within history - within institutions and in real time. So perhaps we have another case of people speaking prose without knowing it?

\section{Simple hypotheses are often the best}

I would venture some simpler hypotheses about why The Economics of Time and Ignorance has not been cited more. First, Jerry O'Driscoll left the academic world for the Federal Reserve Bank of Dallas and later for other non-academic positions. Second, the Austrian program at NYU was effectively deprived of graduate students as the Department of Economics became increasingly more mathematical in every area. Very few students were (are) both sufficiently qualified mathematically and seriously interested in Austrian approaches to be relevant candidates for admission into the NYU doctoral program. Simply put, from the late 1980s on, both O'Driscoll and I were without students (more or less; there were some exceptions). Students are prime citers of their professors' work.

Second, the death of Ludwig Lachmann deprived Austrian economics of a senior voice continually striking the notes of time and ignorance at a fairly high level of theory and methodological awareness. He helped make sure that everyone realized that they were or should be talking prose.

Third, Austrian economics had an embarrassment of riches. Don Lavoie, Peter Boettke, Larry White, Roger Garrison, Steve Horwitz, Peter Lewin, Richard Ebeling, David Harper - to mention only a few in no special order - all moved Austrian economics in a variety of productive directions, both theoretical and applied. Austrians were so excited by the possibilities of research in specific fields that they just did their work. Many pursued a form of institutional analysis. Institutional analysis was one of the ways, we thought and Lachmann thought, a radical subjectivism had to go in order to understand how people deal with the uncertainty of economic life. Perhaps this is all Stein and Storr are saying.

Fourth, of course, the physical book itself began to fade from the scene. It has not been advertised in a long time. For much of the past 15 years it had 
not been available at an inexpensive price. Nor was it available in modern e-book formats. (O’Driscoll and I are trying to remedy these problems.)

\section{Austrian economics today}

Karen Vaughn (1998) said in her study of the Austrian tradition that today Austrian economics is the economics of time and ignorance. By this she meant not that Austrian economics follows our book chapter and verse but that the issues raised, the themes pursued, but above all the openness to new ideas, is the rule now rather than the rare exception. As Peter Boettke has often said, Mises was not shy about criticizing his Austrian forbears, including the great Eugen von Böhm-Bawerk and so we should not fear criticizing previous Austrians when we think it appropriate. We accepted his advice before he gave it!

So what is Austrian economics today? In my New Palgrave article (Rizzo 2009) on Austrian economics I made a stab at answering this question. I listed eight, highly interrelated themes:

1. the subjective, yet socially embedded, quality of human decisionmaking;

2. the individual's perception of the passage of time ("real time");

3. the radical uncertainty of expectations;

4. the decentralization of explicit and tacit knowledge in society;

5. the dynamic market processes generated by individual action, especially entrepreneurship;

6. the function of the price system in transmitting knowledge;

7. the supplementary role of cultural norms and other cultural products ("institutions") in conveying knowledge; and

8. the spontaneous - that is, not centrally directed - evolution of social institutions. ${ }^{1}$

In a session of the Colloquium on Market Institutions and Economic Processes at NYU a few years ago, I presented a draft of the New Palgrave article. One participant objected that I did not tell the reader what Austrian economics is beyond the listing of some themes.

A list of themes is certainly not a definition. But to define a school of thought in precise terms is really inappropriate - almost a category mistake. A framework for scientific thinking must be loosely defined. It cannot predetermine what will be learned within that structure. It must give guidance but not rigid guidance. Its principles must be open to change but, of course, not all at once - and not in just any direction. Yet nothing is sacred. ${ }^{2}$

Even the distinction among schools is a temporary - perhaps a disequilibrium - phenomenon. An objection was raised during the aforementioned colloquium discussion that other schools of thought would subscribe to some or many of the themes. Yes, that was one of the messages of The Economics 
of Time and Ignorance. In the time that has passed since the first edition of the book (1985) some of the overlap has widened across more "schools" while some distinctions among approaches have grown sharper.

The issues that separated Austrians from other schools of thought in previous decades cannot be the same today. Neoclassical economics has developed. It has attempted to capture within its ambit many of the previously uniquely Austrian themes. What separates approaches needs to be continually reassessed. No intellectual approach is standing still. The best work in Austrian economics during the past 35 years or so should be a surprise to any Rip van Winkle who fell asleep at the beginning of the Austrian revival.

So a viable Austrian economics must be a flexible structure that, in accommodating change, can be a vehicle for the growth of knowledge. The true spirit of science, as Karl Popper continually taught, is to recognize that from errors we make some of our most important discoveries. Obviously, it is not that we strive to make errors. But bold thinking will, ex post, often reveal that the scientist was wrong. But we go on. This is the spirit we sought to infuse into the Austrian tradition.

\section{Notes}

1 Much of this institutional analysis appears in what may be called the "Austrian law and economics" literature. See Rizzo (2011).

2 This is Felix Kaufmann's principle of "permanent control" by the scientific community (Kaufmann, 1944: 39).

\section{References}

Davidson, P. (1989). The economics of ignorance or ignorance of economics? Critical Review: A Journal of Politics and Society, 3(3-4), 467-87.

Kaufmann, F. (1944). Methodology of the social sciences. New York and London: Oxford University Press.

Kirzner, I. M. (1994). On the economics of time and ignorance. In P. J. Boettke and D. L. Prychitko (eds.), The market process: Essays in contemporary Austrian economics. Aldershot: Edward Elgar.

Lachmann, L. M. (1976). From Mises to Shackle: An essay on Austrian economics and the kaleidic society. Journal of Economic Literature, 14(1), 54-62.

Lachmann, L. M. (1994). On the economics of time and ignorance. In P. J. Boettke and D. L. Prychitko (eds.), The market process: Essays in contemporary Austrian economics. Aldershot, UK: Edward Elgar.

Popper, K. R. (1979). On the theory of the objective mind. In Objective knowledge: An evolutionary perspective. Oxford: Clarendon Press.

Rizzo, M. J. (2009). Austrian economics: Recent work. In S. N. Durlauf, L. E. Blume (eds.), The New Palgrave dictionary of economics, online edition. Palgrave Macmillan. http://www.dictionaryofeconomics.com/article?id=pde2009_A000258 doi:10.1057/9780230226203.1915.

Rizzo, M. J. (2011). Introduction. In M. J. Rizzo (ed.), Austrian law and economics, vol 1. Cheltenham, UK: Edward Elgar. 


\section{Responses to criticism}

Rothbard, M. N. (2011). The present state of Austrian economics. In Economic controversies. Auburn, Ala.: Ludwig von Mises Institute.

Vaughn, K. I. (1998). Austrian economics in America: The migration of a tradition. Cambridge: Cambridge University Press. 